4-1992

\title{
Effects of Hypoxia and Anoxia on Larval Settlement, Juvenile Growth, and Juvenile Survival of the Oyster Crassostrea virginica
}

SM Baker

Virginia Institute of Marine Science

Roger L. Mann

Virginia Institute of Marine Science

Follow this and additional works at: https://scholarworks.wm.edu/vimsarticles

Part of the Aquaculture and Fisheries Commons

\section{Recommended Citation}

Baker, SM and Mann, Roger L., Effects of Hypoxia and Anoxia on Larval Settlement, Juvenile Growth, and Juvenile Survival of the Oyster Crassostrea virginica (1992). Biological Bulletin, 182(2), 265-269. $10.2307 / 1542120$

This Article is brought to you for free and open access by the Virginia Institute of Marine Science at W\&M ScholarWorks. It has been accepted for inclusion in VIMS Articles by an authorized administrator of W\&M ScholarWorks. For more information, please contact scholarworks@wm.edu. 


\title{
Effects of Hypoxia and Anoxia on Larval Settlement, Juvenile Growth, and Juvenile Survival of the Oyster Crassostrea virginica
}

\author{
S. M. BAKER AND R. MANN \\ Virginia Institute of Marine Science, The College of William and Mary, \\ Gloucester Point, Virginia, 23062
}

\begin{abstract}
The effects of hypoxia (1.5 $\mathrm{mg} \mathrm{O}_{2} 1^{-1}, 20 \%$ of air saturation) and anoxia ( $<0.07 \mathrm{mg} \mathrm{O}_{2} 1^{-1},<1 \%$ of air saturation) on oyster (Crassostrea virginica) larval settlement, juvenile growth, and juvenile survival were studied. Settlement was reduced significantly $(P<0.05)$ in hypoxic treatments, as compared to normoxic treatments (7.3 $\mathrm{mg} \mathrm{O}_{2} \mathrm{~h}^{-1}, 100 \%$ of air saturation), and almost no settlement took place in anoxic treatments. After $96 \mathrm{~h}$, $38 \%$ and $4 \%$ of the larvae placed in hypoxic and anoxic treatments had settled, while $79 \%$ settled in normoxic treatments. In the first $144 \mathrm{~h}$ after settlement, juveniles in hypoxic treatments grew one third as much as those in normoxic treatments, while juveniles in anoxic treatments did not grow at all. Median mortality times of recently settled juveniles in hypoxic and anoxic treatments were $131 \mathrm{~h}$ and $84 \mathrm{~h}$, respectively. We conclude that hypoxic and anoxic waters have potentially detrimental effects on oyster settlement and recruitment.
\end{abstract}

\section{Introduction}

Chesapeake Bay exhibits episodes of oxygen depletion concomitant with seasonal salinity and temperature stratification (Taft et al., 1980; Officer et al., 1984). Oxygen depletion is usually restricted to areas below the pycnocline, but wind stress frequently tilts the pycnocline (Carter et al., 1978; Malone et al., 1986) irrigating shallow areas, where oyster reefs occur, with hypoxic or anoxic water from deeper areas (May, 1973; Sanford et al., 1990). The pycnocline remains tilted for from several hours to two or three days (Malone et al., 1986; Sanford et al., 1987).

Received 26 August 1991; accepted 25 November 1991.

Contribution No. 1707 from the Virginia Institute of Marine Science, School of Marine Science, The College of William and Mary.
These events often coincide with the timing of settlement and recruitment of the oyster, Crassostrea virginica Gmelin. Reduced settlement or complete settlement failure in localized areas has been attributed to incidents of pycnocline tilting (May, 1973; Abbe, 1986).

Previous studies have demonstrated that tolerance of larval and adult oysters to hypoxia and anoxia increases with developmental stage and body size. Larval stages and juvenile oysters ( $16 \mathrm{~mm}$ height) survive anoxia from hours to days (Widdows et al., 1989), while adult oysters survive periods of unsuitable conditions lasting days or weeks (Galtsoff, 1964; Stickle et al., 1989).

Little is known about the tolerance of settling oyster larvae or recently settled juvenile oysters to hypoxia and anoxia. These stages are pivotal to subsequent recruitment into the population. The objectives of this study, therefore, were to examine the effects of hypoxia and anoxia on settlement of oyster pediveliger larvae and on the growth and survival of recently settled juvenile oysters.

\section{Materials and Methods}

\section{Experimental apparatus}

All experiments were performed at $25^{\circ} \mathrm{C}$ and $21 \% \mathrm{~S}$. Temperature was maintained by controling laboratory temperature and by a circulating water bath in which the experimental chambers were immersed. Three 4-liter flasks of $0.45 \mu \mathrm{m}$ filtered seawater containing algae (Isochrysis galbana) at a concentration of 20,000 cells $\mathrm{ml}^{-1}$ were bubbled with air, a mixture of oxygen and nitrogen, or nitrogen. The target oxygen concentrations were 7.3 $\mathrm{mg} \mathrm{O}_{2} \mathrm{I}^{-1}$ (100\% of air saturation), $1.5 \mathrm{mg} \mathrm{O}_{2} \mathrm{1}^{-1}$ (20\% of air saturation), and less than $0.07 \mathrm{mg} \mathrm{O}_{2} 1^{-1}$ (<1\% of air saturation). These treatments will be referred to as 
normoxia, hypoxia, and anoxia, respectively, although the latter of these conditions is more correctly termed 'microxia.' Although carbon dioxide was not included in the latter two treatments, $\mathrm{pH}$ did not differ significantly $(P$ $<0.05$, ANOVA) among the three treatments.

Flow-through chambers were constructed to hold larval and juvenile oysters during experimental trials. Each chamber was a $20 \mathrm{ml}$ glass vial closed with a rubber stopper pierced by two 20 gauge needles. Inflow needles were fitted with inverted pipette tips. Outflow needles were cut off even with the bottom of the stoppers and covered with $202 \mu \mathrm{m}$ Nitex mesh, fine enough to retain pediveliger larvae. Chambers within the same treatment were connected in series as depicted in Figure 1. Stainless steel tubing ( $1 \mathrm{~mm}$ bore) was used throughout. The flow rate through the chambers was about $233 \mathrm{ml} \mathrm{h}^{-1}$, and water residence time in the system was $1 \mathrm{~h}$ or less. The flasks of seawater and algae were replaced every $12 \mathrm{~h}$ with identical flasks that had been bubbled with the appropriate gases for at least $2 \mathrm{~h}$ prior to replacement.

Oxygen concentration at the outflow of each treatment was measured daily with a Strathkelvin Instruments (SI) oxygen sensor (1302) held in a SI microcell (MC100) and coupled to a SI oxygen meter (781) and chart recorder. The oxygen sensor was calibrated daily with air-saturated water and a $0 \%$ oxygen solution of sodium borate and crystalline sodium sulfite. Normoxic, hypoxic, and anoxic treatments were consistently maintained at $85-100 \%$, 15$22 \%$ and $0-1 \%$ of full air saturation, respectively. Outflow concentrations of oxygen did not differ measurably from the inflow concentrations.

\section{Larval settlement experiments}

Oyster (Crassostrea virginica) pediveliger larvae were reared by the Virginia Institute of Marine Science oyster hatchery at Gloucester Point, Virginia. Oyster shell settlement substrates were conditioned in seawater for $24 \mathrm{~h}$ prior to each experiment to develop a settlement-inducing bacterial coating (Fitt et al., 1990). One conditioned oyster shell was placed in each chamber, with the rough side up. Fifty larvae were counted into each chamber with a Drummond Captrol III microdispensor. Only actively swimming larvae were used.

Two chambers were removed daily from each treatment; they were not replaced. Settlement was calculated by expressing the number of settled oyster larvae as a percentage of the total number of larvae introduced into the chamber. The data from the two chambers were pooled as one replicate for that exposure time. The entire larval settlement experiment was repeated five times, resulting in five replicates of normoxic treatments, and three replicates each of hypoxic and anoxic treatments.

Larval settlement data were arcsine transformed, and analysis of variance was performed for each exposure time to test the null hypothesis that the means of the three treatments were equal. For those exposure times in which the null hypothesis was rejected, the Tukey multiple comparison test was performed to determine between which treatment means differences existed (Zar, 1984). Means and standard deviations were back transformed for report in Figure 2.

\section{Juvenile growth and survival experiments}

Unless otherwise noted, the term "juvenile" is used in this paper to refer to those oysters $144 \mathrm{~h}$ post settlement or less. Oyster pediveliger larvae were allowed to settle on conditioned oyster shells for $2 \mathrm{~h}$ just prior to commencement of the experiments. Non-settled larvae were washed off after $2 \mathrm{~h}$. One oyster shell with settled larvae was placed in each chamber, with the rough side up. Two chambers were removed daily from each treatment; they were not replaced. Twenty-five randomly selected live juvenile oysters from each of the two chambers were measured with a compound microscope and an ocular micrometer. Growth was measured as the amount of new shell in the dorsal-ventral axis (height). Mortality was recorded as the proportion of dead juveniles among 50 randomly selected juveniles from each chamber. The data from the two chambers were pooled as one replicate for that exposure/ post settlement time. The entire juvenile growth and survival experiment was repeated four times, resulting in four replicates of normoxic treatments, and three replicates each of hypoxic and anoxic treatments.

Growth data were log transformed, and the residuals were examined for homoscedasticity. Analysis of variance was performed to test significance and linearity of the growth regressions. Student's $t$ test was used to determine differences between the normoxic and hypoxic growth regression coefficients and regression elevations (Zar, 1984).

Survival data for juvenile oysters were arcsine transformed. Analysis of variance was performed for each exposure/post settlement time to test the null hypothesis that the means of the three treatments were equal. For those exposure/post settlement times in which the null hypothesis was rejected, the Tukey multiple comparison test was performed to determine between which treatment means differences existed (Zar, 1984). Means and standard deviations were back transformed for report in Figure 4.

\section{Results}

\section{Larval settlement}

In normoxic treatments at $24 \mathrm{~h}$, the mean settlement of oyster larvae was $38 \%$ (Fig. 2). The percentage of settled larvae increased $10-20 \%$ per day, and was $79 \%$ at $96 \mathrm{~h}$. In the hypoxic treatments, settlement was $18 \%$ at $24 \mathrm{~h}$ 


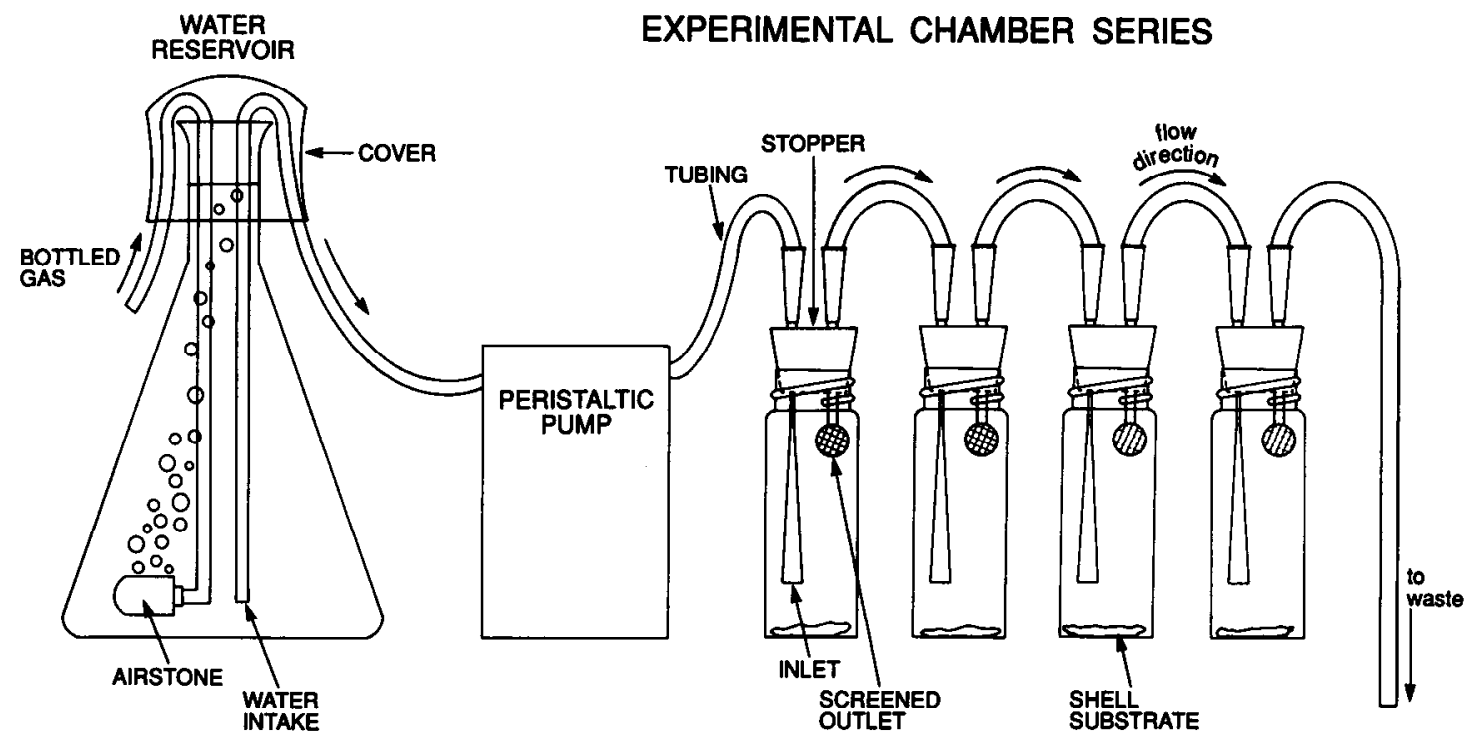

Figure 1. The experimental apparatus. Four chambers of one treatment are shown. Flasks of seawater were bubbled with air, a mix of oxygen and nitrogen, or nitrogen. The equilibrated seawater was pumped through chambers containing settlement substrate and pediveliger larvae or juveniles of the oyster Crassostrea virginica. Flow-through chambers were immersed in a circulating water bath of $25^{\circ} \mathrm{C}$. (Not drawn to scale.)

and $38 \%$ at $48 \mathrm{~h}$. After $48 \mathrm{~h}$, hypoxic treatments had no further settlement. In anoxic treatments, settlement was $4 \%$ at $24 \mathrm{~h}$, with no subsequent settlement. At $24 \mathrm{~h}$, anoxic and normoxic treatment means were significantly different $(P<0.05)$, and at $48 \mathrm{~h}$, the anoxic treatment mean was significantly different $(P<0.05)$ from both the hypoxic and normoxic treatment means. At 72 and $96 \mathrm{~h}$, all three treatment means were significantly different $(P<0.05)$ from each other.

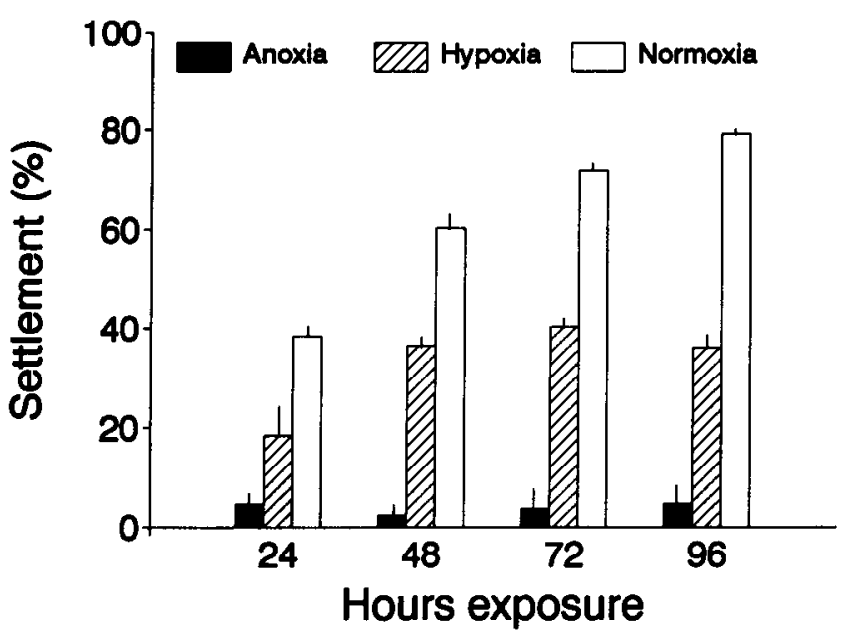

Figure 2. Relation between percentage settlement of oyster (Crassostrea virginica) pediveliger larvae and duration of normoxic $(7.3 \mathrm{mg}$ $\left.\mathrm{O}_{2} \mathrm{1}^{-1}\right)$, hypoxic $\left(1.5 \mathrm{mg} \mathrm{O}_{2} \mathrm{1}^{-1}\right)$, and anoxic $\left(<0.07 \mathrm{mg} \mathrm{O}_{2} \mathrm{1}^{-1}\right)$ treatments. (Means $+\mathrm{SD}$; normoxia $\mathrm{n}=5$; hypoxia $\mathrm{n}=3$; anoxia $\mathrm{n}=3$.)

\section{Juvenile growth}

Regressions of log transformed juvenile oyster growth data from normoxic and hypoxic treatments were linear and significant. The regression coefficients of the normoxic and hypoxic treatments were not significantly different; however, the regression elevations were significantly different $(P<0.05)$ from each other (Fig. 3). Juveniles in the normoxic treatments grew over $255 \mu \mathrm{m}$ of new shell

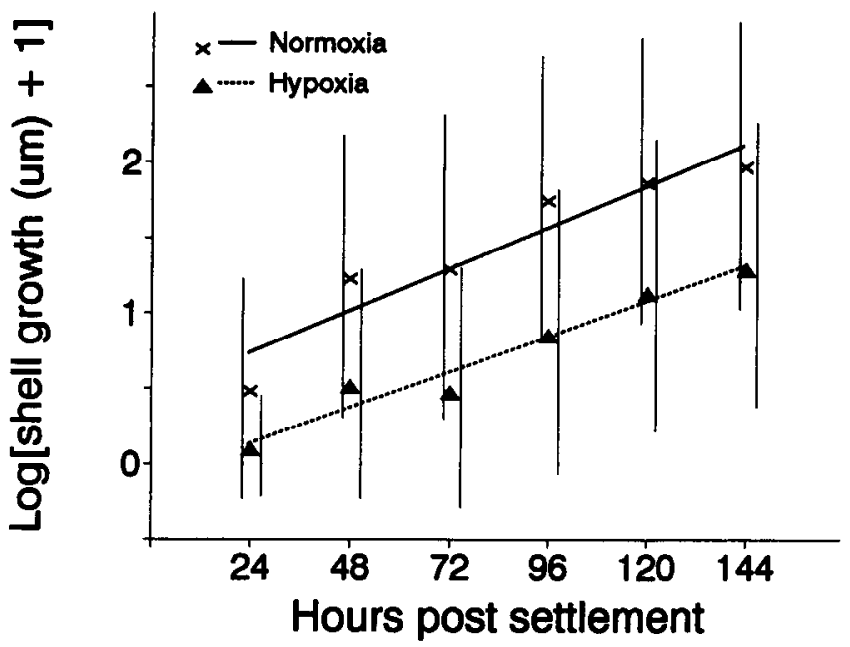

Figure 3. Log of growth of Crassostrea virginica juveniles (initial shell height $290 \mu \mathrm{m})$ in normoxic $\left(7.3 \mathrm{mg} \mathrm{O}_{2} 1^{-1}\right)$, hypoxic $(1.5 \mathrm{mg} \mathrm{O}$ $\left.1^{-1}\right)$, and anoxic ( $\left.<0.07 \mathrm{mg} \mathrm{O}_{2} 1^{-1}\right)$ treatments in relation to hours post settlement. (Means $\pm \mathrm{SD}$; normoxia $n=175$ for each mean marker; hypoxia $n=125$ for each mean marker.) 
in $144 \mathrm{~h}$, nearly doubling in length. Juveniles in hypoxic treatments grew only $77 \mu \mathrm{m}$ of new shell in $144 \mathrm{~h}$, approximately one third as much as those in normoxic treatments. Juveniles in anoxic treatments did not increase in shell height.

\section{Juvenile survival}

Juvenile oyster survival was similar in all three treatments for the first $72 \mathrm{~h}$ (Fig. 4). At $96 \mathrm{~h}$ and $120 \mathrm{~h}$, the anoxic treatment mean was significantly different $(P$ $<0.05$ ) from both hypoxic and normoxic treatment means. All three treatment means were significantly different $(P<0.05)$ from each other at $144 \mathrm{~h}$. Juveniles in the anoxic treatments had a median mortality time (time to $50 \%$ mortality) of $84 \mathrm{~h}$. Mortality of juveniles in anoxic treatments was $100 \%$ by $144 \mathrm{~h}$. Juveniles in the hypoxic treatments had a median mortality time of $131 \mathrm{~h}$. Normoxic treatments, in contrast, had a mean of only $13 \%$ mortality at $144 \mathrm{~h}$.

\section{Discussion}

Under hypoxic and anoxic conditions, oyster pediveliger larvae significantly reduce energetically costly activities, thereby reducing total metabolism and oxygen requirements (Widdows et al., 1989). The results of this study indicate that settlement is another costly activity that oyster pediveliger larvae avoid when in oxygen-limiting environments.

In a recent paper on the effects of hypoxia and anoxia on Mytilus edulis larvae, Wang and Widdows (1991) report that moderate hypoxia has little effect on larval settlement. Settlement of mussel pediveliger larvae onto adult byssus filaments is approximately $12 \%$ after two days in conditions of $8.2 \mathrm{mg} \mathrm{O}_{2} 1^{-1}\left(20.0 \mathrm{kPa}^{2} \mathrm{O}_{2}, 98 \%\right.$ of air saturation at $15^{\circ} \mathrm{C}$ and $\left.31 \% 0\right), 2.4 \mathrm{mg} \mathrm{O}_{2} 1^{-1}(5.91 \mathrm{kPa}$ $\mathrm{pO}_{2}, 29 \%$ of air saturation), or $1.3 \mathrm{mg} \mathrm{O} 1^{-1}(3.16 \mathrm{kPa}$ $\mathrm{pO}_{2}, 15 \%$ of air saturation). An oxygen concentration of $0.6 \mathrm{mg} \mathrm{O}_{2} 1^{-1}\left(1.38 \mathrm{kPa} \mathrm{pO}_{2}, 7 \%\right.$ of air saturation) shows $1 \%$ settlement. Settlement of $C$. virginica appears to be more sensitive to moderate hypoxia than mussel settlement. While settlement of mussel larvae is unchanged in treatments of $8.2 \mathrm{mg} \mathrm{O}_{2} 1^{-1}$ down to $1.3 \mathrm{mg} \mathrm{O}_{2} 1^{-1}$ (Wang and Widdows, 1991), oyster larval settlement was significantly reduced by oxygen concentrations of $1.5 \mathrm{mg} \mathrm{O} \mathrm{O}_{2}$ $1^{-1}$ or less. The estimated oxygen concentration at which settlement after two days is $50 \%$ of that in normoxic treatments is $0.9 \mathrm{mg} \mathrm{O}_{2} 1^{-1}$ (10\% of air saturation) for mussel larvae (Wang and Widdows, 1991) compared to $1.4 \mathrm{mg}$ $\mathrm{O}_{2} 1^{-1}$ (20\% of air saturation) for oyster larvae. While oysters are entirely sessile once they have settled, post larval mussels migrate repeatedly before arriving at a final settlement site (Lane et al., 1985). Larval mussels, there-

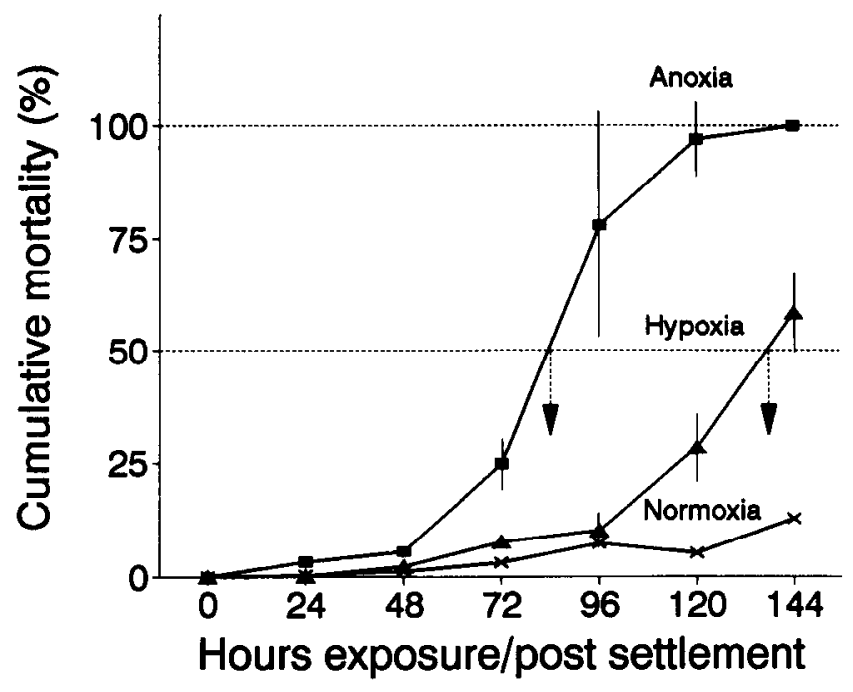

Figure 4. Relation between cumulative mortality of Crassostrea virginica juveniles and duration of normoxic $\left(7.3 \mathrm{mg} \mathrm{O}_{2} 1^{-1}\right)$, hypoxic $(1.5$ mg O $\left.\mathrm{O}_{2} \mathrm{1}^{-1}\right)$, and anoxic $\left(<0.07 \mathrm{mg} \mathrm{O}_{2} \mathrm{1}^{-1}\right)$ treatments. Arrows indicate median mortality times. Where no standard deviation is shown, the standard deviation is smaller than the mean marker. (Means $\pm \mathrm{SD}$; normoxia $n=4$; hypoxia $n=3$; anoxia $n=3$ )

fore, do not need to be as discriminating as oyster larvae when selecting a suitable settlement habitat.

In other aspects of their physiology, oyster larvae are less sensitive to oxygen deprivation than are mussel larvae. For example, the oxygen concentration at which the respiration rate is $50 \%$ of the normoxic rate is $2.3 \mathrm{mg} \mathrm{O}_{2} 1^{-1}$ (5.7 $\mathrm{kPa} p \mathrm{O}_{2}, 28 \%$ of air saturation) for mussel pediveliger larvae (Wang and Widdows, 1991) and $0.9 \mathrm{mg} \mathrm{O}_{2} 1^{-1}$ $\left(2.3 \mathrm{kPa} p \mathrm{O}_{2}, 11 \%\right.$ of air saturation at $22^{\circ} \mathrm{C}$ and $12 \%$ ) for oyster pediveliger larvae (Widdows et al., 1989). The $10^{\circ} \mathrm{C}$ difference in temperature at which the mussel (Wang and Widdows, 1991) and oyster (this paper) settlement experiments were performed, and the resulting differences in metabolic rates, may have contributed to the discrepancy observed in oxygen sensitivity of mussel and oyster larval settlement. At $15^{\circ} \mathrm{C}$, mussel pediveliger larvae have a normoxic oxygen uptake of $75 \mathrm{pmol} \mathrm{O}_{2} \mathrm{~h}^{-1}$ larva $^{-1}$ (Wang and Widdows, 1991), while at $22^{\circ} \mathrm{C}$, oyster pediveliger larvae have an oxygen uptake of $400 \mathrm{pmol} \mathrm{O}_{2} \mathrm{~h}^{-1}$ larva $^{-1}$ (Widdows et al., 1989).

As discussed earlier, pediveliger larvae reduce energetically costly activities during hypoxic exposure, such as ingestion, digestion, and growth, thereby reducing oxygen demand. Under hypoxic conditions, there is a marked decline in the proportion of pediveliger larvae feeding and in ingestion rates (Widdows et al., 1989). Mussel pediveliger larvae also exhibit depressed feeding rates and growth in hypoxic conditions (Wang and Widdows, 1991). The reduction of juvenile oyster growth in hypoxic treatments and complete lack of growth in anoxic treatments 
observed in this study may have resulted from a cessation of feeding.

In this study, juvenile oysters had a median mortality time of $84 \mathrm{~h}$ in anoxia. This indicates that, like oyster larvae and adults, recently settled juvenile oysters are capable of anaerobic metabolism. Widdows et al. (1989) report median mortality times in anoxia of 11,18 , and $51 \mathrm{~h}$ for oyster prodissoconch, veliconch, and pediveliger larvae, and $150 \mathrm{~h}$ for juveniles $16 \mathrm{~mm}$ in shell height. The data for recently settled juveniles are consistent with the trend of increasing anoxic tolerance with developmental stage and body size. The increased median survival time in later stages is associated with an ability to reduce energy use, measured as heat dissipation, under anoxic conditions (Widdows et al., 1989). The degree of heat dissipation reduction by recently settled juvenile oysters in anoxia is expected to be between that of the pediveliger larvae and $16 \mathrm{~mm}$ juveniles studied by Widdows et al. (1989).

Further studies on feeding, heat dissipation, and oxygen uptake are required to understand more clearly the effects of anoxia and hypoxia on settling pediveliger larvae and recently settled juvenile oysters. The present study does demonstrate that hypoxic and anoxic conditions have detrimental effects on larval settlement, juvenile growth, and juvenile survival. Oyster distribution may be influenced by anoxia and hypoxia, especially in those areas that experience prolonged (longer than 48 to $72 \mathrm{~h}$ ) or severe (anoxic) pycnocline tilt events. Pycnocline tilt events may control recruitment into the adult population directly, because of larval settlement failure and juvenile mortality, and indirectly, because of a reduction in the growth rate of juveniles.

\section{Acknowledgments}

This study was supported by funds from the National Oceanic and Atmospheric Administration to RM and the International Women's Fishing Association to SMB. We thank the staff of the VIMS oyster hatchery for the provision of larvae. P. Baker, B. Barber, L. Schaffner,
R. I. E. Newell, and two anonymous reviewers made helpful comments on the manuscript.

\section{Literature Cited}

Abbe, G. R. 1986. A review of some factors that limit oyster recruitment in Chesapeake Bay. Am. Malacol. Bull., Special Edition No. 3: 5970.

Carter, H. H., R. J. Regier, E. W. Schiemer, and J. A. Michael. 1978. The summertime vertical distribution of dissolved oxygen at the Calvert Cliffs generating station: a physical interpretation. Chesapeake Bay Institute, The Johns Hopkins University, Special Report 60: 1-95.

Fitt, W. K., S. L. Coon, M. Walch, R. M. Weiner, R. R. Colwell, and D. B. Bonar. 1990. Settlement behavior and metamorphosis of oyster larvae (Crassostrea gigus) in response to bacterial supernatants. Mar. Biol. 106: 389-394.

Galtsoff, P.S. 1964. The American Oyster Crassostrea virginica Gmelin. Fish. Bull. Fish Wildlife Ser. 64: 1-480.

Lane, D. J. W., A. R. Beaumont, and J. R. Hunter. 1985. Byssus drifting and the drifting threads of the young post-larval mussel Mytilus edulis. Mar. Biol. 84: 301-308.

Malone, T. C., W. M. Kemp, H. W. Ducklow, W. R. Boynton, J. H. Tuttle, and R. B. Jonas. 1986. Lateral variation in the production and fate of phytoplankton in a partially stratified estuary. Mar. Ecol. Prog. Ser. 32: 149-160.

May, E. B. 1973. Extensive oxygen depletion in Mobile Bay, Alabama. Limnol. Oceanogr. 18(3): 353-366.

Officer, C. B., R. B. Biggs, J. L. Taft, L. E. Cronin, M. A. Tyler, and W. R. Boynton. 1984. Chesapeake Bay anoxia: origin, development, and significance. Stience 223: 22-27.

Sanford, L. P., K. G. Sellner, and D. L. Breitburg. 1990. Covariability of dissolved oxygen with physical processes in the summertime Chesapeake Bay. J. Mar. Res. 48: 567-590.

Sanford, L., K. Sellner, and M. Bundy. 1987. Moored measurements of dissolved oxygen in the Chesapeake Bay during the summer of 1987. AGU Ocean Sciences Meeting, New Orleans, LA, 1987.

Stickle, W. B., M. A. Kapper, L.-L. Liu, E. Gnaiger, and S. Y. Wang. 1989. Metabolic adaptations of several species of crustaceans and molluscs to hypoxia: tolerance and microcalorimetric studies. Divi. Bull. 177: 303-312.

Taft, J. L., E. D. Hartwig, and R. Loftus. 1980. Seasonal oxygen depletion in Chesapeake Bay. Estuaries 3(4): 242-247.

Wang, W. X., and J. Widdows. 1991. Physiological responses of mussel larvae Mytilus edulis to environmental hypoxia and anoxia. Mar. Ecol. Prog. Ser. 70: 223-236.

Widdows, J., R. I. E. Newell, and R. Mann. 1989. Effects of hypoxia and anoxia on survival, energy metabolism, and feeding of oyster larvae (Crassostrea virginica, Gmelin). Biot. Bull. 177: 154-166.

Zar, J. H. 1984. Biostatistical Analysis. Prentice-Hall, Englewood Cliffs, New Jersey. 